\title{
A study of Adjustment Problem among working women and non working women
}

\author{
Kachchhi Parvati K*.
}

\begin{abstract}
The main purpose was to find out the main difference between working and non working women in adjustment problem. The total sample consisted 200 women in working non working women. The research tool for Bell's adjustment inventory. Here ' $t$ ' test was applied to check the significance of difference in adjustment problem. The study revealed the working women and non working women were adjustment well especially from 'social, emotional and Health adjustment. The results showing that working women are more adjustment in terms of Health, Social and Emotional adjustment than non working women.
\end{abstract}

\section{INTRODUCTION:}

The average person when asked "What do you want life?" will answer in words synonymous with happiness. This in Psychological language mans the pursuit of satisfactions of his various needs as they become active each day we must have built up habits, attitudes and trains that are appropriate. To be as successful public speaker or athlete, for example, we must have learned the necessary skill.

In the modern worlds changing pattern of society, technological development have resulted in more and Indian women to be educated and taking up occupations, At the same time they cannot separated them salves from various responsibilities of family and at the social front. A women has to play multiple roles. Thus complexity increases if she is a working women. They have to balance home as well as the job. This overload causes in them stress and strain. The changing status pattern of Indian working women not only influences their societal role at the same time but also their attitudes behavior and their personality. The problems of working women are various types such as psychosocial and professional.

\section{METHOD:}

\section{Objectives: Objectives of the study are as under to}

1. To check the significant difference between the Health, adjustment of working and non working women.

2. To check the significant difference between the social adjustment of working and non working women.

3. To check the significant difference between the Emotional adjustment of working and non working women.

*Associate Professor, Shree Devmani Arts \& Commerce College, Visavadar - 362 130, GUJARAT 


\section{Hypothesis:}

1. There is no significant difference between the Health adjustment of working and non working women.

2. There is no significant difference between the social adjustment of working and non working women.

3. There is no significant difference between the emotional adjustment of working and non working women.

Sample: The purpose of present investigation randomly samples selection system has been adopted in this system 200 women. Out of 300 has been selected randomly. In 200 Samples there are 100 working women and 100 non working women.

Tools: To collect the data investigator will use following tools. Bell's adjustment inventory was used the investigate adjustment among working and non working women.

\section{Results and discussion:}

Table of mean so and' $t$ ' value of working and non working women in terms of Health, Social and Emotional adjustment.

\begin{tabular}{|l|l|l|l|l|l|l|}
\hline Variable & $\begin{array}{l}\text { Category of } \\
\text { women }\end{array}$ & $\mathbf{n}(\mathbf{N})$ & mean & SD & \multirow{2}{*}{ 't' Value } & sig \\
\hline \multirow{2}{*}{ Health } & Working & 100 & 18.08 & 6.53 & 3.62 & 0.01 \\
\cline { 2 - 6 } & Non working & 100 & 20.80 & 9.01 & & \\
\hline \multirow{2}{*}{ Social } & Working & 100 & 17.90 & 6.81 & 5.09 & 0.01 \\
\cline { 2 - 5 } & Non working & 100 & 13.44 & 4.56 & & \\
\hline \multirow{2}{*}{ Emotional } & Working & 100 & 22.09 & 8.10 & 2.28 & 0.05 \\
\cline { 2 - 5 } & Non working & 100 & 19.11 & 6.05 & & \\
\hline
\end{tabular}

\section{Conclusions:}

1. Working women are more adjustment in Health than non working women.

2. Working women are more positive adjustment in social than non working women.

3. Working women are more adjustment in emotional then non working women.

Table show health adjustment of working and non working women. It has been found that there is significant difference among them with respect to health adjustment $(t=3.62<0.01)$. It may be brave working women are diet and health conscious than non working women.

Social adjustment is found in better working women then non working women (mean value of working women $=17.90$ mean value of non working women $=13.44$ ) the calculated ' $t$ ', value is 5.09 , this may be due to more social networking of working women at the job aria than non working women. 
Emotional adjustment is again better in working women. The calculated' $t$ ' value is 2.28 working women go outside their home may have strong social net working to desire share their feelings, worries similarly they are economically independent and have a sense of identity in he society. This makes them emotionally and socially more secure than non working women.

\section{References:}

1. Alport, F.H. (1924), Social psychology, Boston Hought in miffin pp 235 - 276.

2. Bogardus, E.S. (1931), Fundamentals of social psychology new jourks.

3. Kapoor pramila (1970) marriage and working women in India Delhi : Vikas publishing house.

4. Schultz, Linda bag (1978), Role preference congenity and marital satisfaction Diss abst 30, P $57-47$.
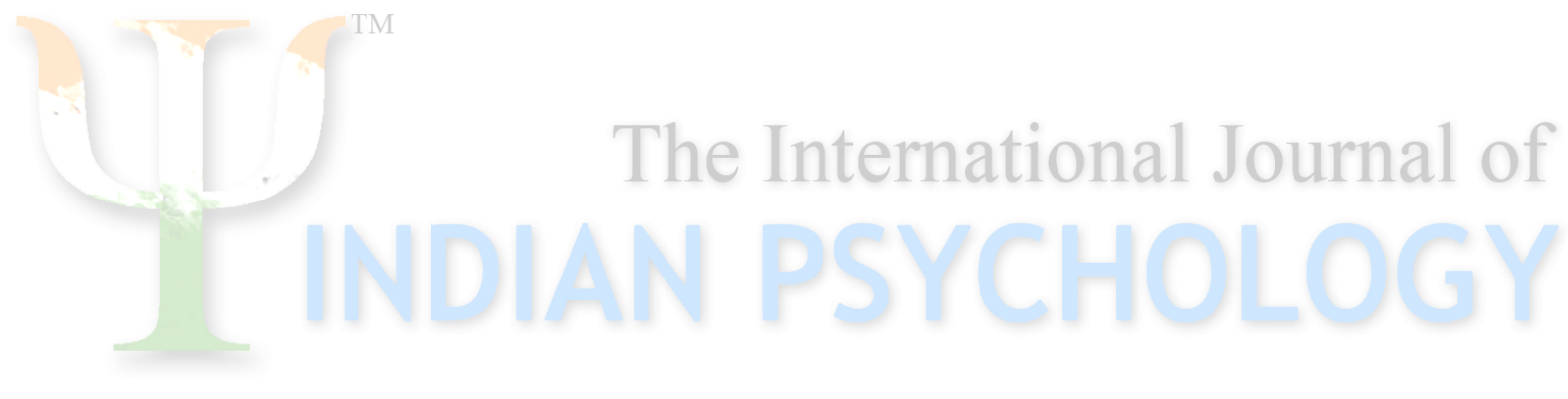